J. Japan. Soc. Hort. Sci. 49(3) : 392-396. 1980.

\title{
Studies on Crosses between Distantly Related Species of Lilies
}

\author{
VI. Pollen-tube Growth in Interspecific Crosses on Lilium longiflorum ( I )
}

\author{
Yoshito Asano \\ Faculty of Agriculture, Hokkaido University, Sapporo 060
}

\begin{abstract}
Summary
Interclonal (compatible) crosses: In each species, in vivo pollen-tube growth after stigmatic pollination was remarkably accelerated as compared with in vitro growth on stigma-exudate medium. A certain stylar factor which accelerates pollentube growth appeared to actuate between 5 and 12 hours after pollination.

Interspecific (incompatible) crosses: In vivo pollen-tube growth in the case of interspecific stigmatic pollination on L. longiflorum was the same as or a little better than that in the case of in vitro 'interclonal stigma-exudate pollination' and not accelerated as in the case of interclonal stigmatic pollination. This may indicate that the poor pollen-tube growth in interspecific crosses is not a result of 'inhibition' but rather results from impossibility of utilization of an accelerative factor in the style. In one species, however, pollen-tube growth was inhibited, showing abnormalities such as a swelled tube-tip between 12 and 24 hours after pollination.
\end{abstract}

\section{Introduction}

It has been noticed that the cross incompatibility between distantly related species of Lilium was primarily caused by insufficient pollen-tube growth in the style despite good pollen germination on the stigma and tube penetration into the style $(3,4,11)$. The intrastylar (cut stylar) pollination technique, where pollens were put just above the top of ovary, has been ascertained to be partly effective in overcoming incompatibility of this type (1). However, when pollen-tube growth is very poor, incompatibility is still a problem even using this technique. In the present paper, the mechanism of poor pollen-tube growth was investigated in order to obtain basic knowledge which might be used to overcome incompatibilities.

\section{Materials and Methods}

Interspecific crosses, L.longiflorum was used as a pistil donor and pollinated on the stigma with another species. Pollen-tube growths were observed not only after pollination on the stigma but also on stigma-

Received for publication February 14, 1980. exudate. For the in vitro growth tests using stigma-exudate, a large modified van Tieghem's cell was utilized. As shown in Fig. 1, stigma-exudate was spread on the center of a glass slide of $8.2 \times 5.2 \mathrm{~cm}$; After pollination on the culture medium, the slide was placed upside down on a $5 \mathrm{~cm}$ petri dish which held a little water at the bottom, and sealed with Vaseline. At first, pollens were placed on the culture medium in a straight row, using the method given by Iwanami (6): Touch the spread pollens with the edge of a cover glass where a bit of the medium has been applied and transfer the stuck pollens to the surface of the culture medium by another touch. The pollens thus sown send their tubes out almost rectangularly, in orderly rows, so that it is easy to measure their lengths. In all cases, pollens were cultured under incubation at $25^{\circ} \mathrm{C}$ in the dark. After incubation, styles were split lengthwise with a razor blade and the pollentubes in the exposed stylar canals were stained with cotton blue solution and observed under a microscope. Pollen-tubes on stigma-exudate were measured directly on the slide using a micrometer. The lengths of the pollen-tubes in each replicate were 


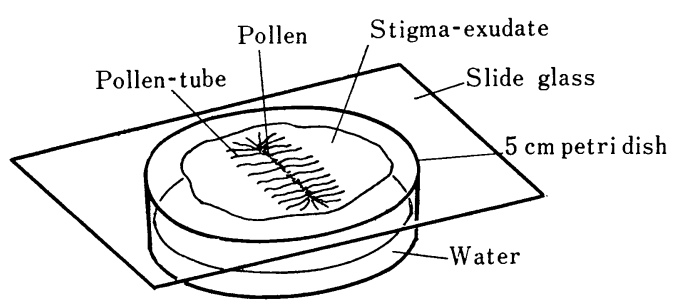

Fig.1. A modified van Tieghem's cell used for the observation of the pollen-tube growth on stigma-exudate medium.

\section{Results}

averaged to give a mean length.

Interclonal (compatible) crosses:

Pollen-tube growths in interclonal (intraspecific) stigmatic pollination and on stigmaexudate mediums from other clones ('interclonal stigma-exudate pollination') were compared in 5 respective species of Lilium; results are included in Fig. 2 (stigma-exudate was not gathered in L.amabile). Unlike the growth on stigma-exudate, pollen-tube growth in the style is apparently accelerated in each species within 12 hours after pollination. In making comparisons between the species, significant differences at the $\mathrm{P}=0.01$ level were recognized in in-style growths among the six species studied, and also in growths on stigma-exudate among the five species from which exudate was gathered. Fig. 3 shows pollen-tube growths in interclonal stigmatic and 'stigma-exudate' pollination of L.longiflorum at 1, 2.5, 5 and 12 hours after pollination. There was no significant difference between the two pollen-tube growths in the first 5 hours. But, 12 hours after pollination, definite difference appeared, the pollen-tube in the style being about double the length of that on the stigmaexudate. The growth of the former describes a parabola while the latter shows a nearly rectilinear figure.

Interspecific (incompatible) crosses:

The pollen-tube growth in interspecific stigmatic pollination was compared with growth in both interclonal stigmatic and 'stigma-exudate' pollination within each species (Fig. 2). The results in Figure 2 indicate that, as long as 12 hours after pollination, pollen-tube growths in interspecific stigmatic pollinations are much worse than those in interclonal stigmatic pollinations, and are the same or a little better than

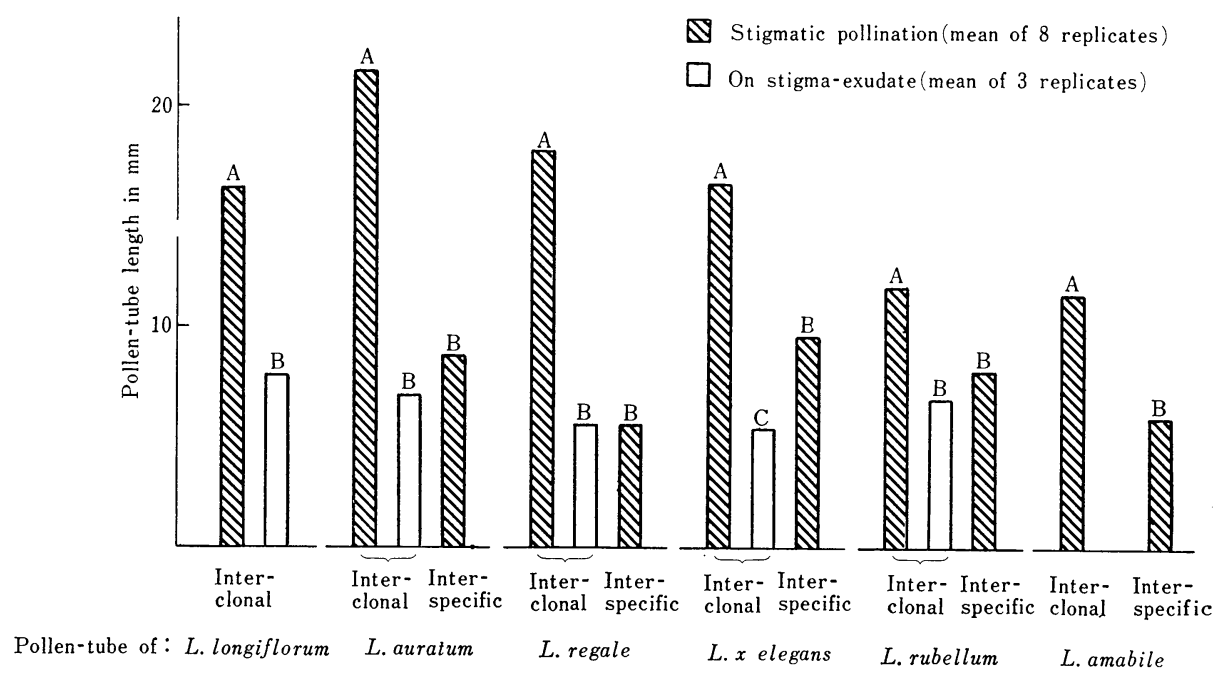

Fig.2 Comparison of pollen-tube growths in interclonal stigmatic- and 'stigma-exudate'-pollination and in interspecific stigmatic pollination on L. longiflorum : after 12 hours incubation. Differences within species, designated by letters above histogram bar, were determined by Duncan's New Multiple Range Test, 0.05. 
those on stigma-exudates. Pollen-tube growths of 6 species up to 24 hours after stigmatic pollinations on L.longiflorum are shown in Fig. 4. Pollen-tubes in four of the interspecific crosses grew at the same or somewhat better rates in the second 12 hours than in the first 12 hours, but in one case (L. regale), growth was apparently inhibited during the second 12 hours and the tubes showed abnormalities such as swelled tips.

\section{Discussion}

Interclonal crosses:

It has been reported that the bulk of organic compounds present in stigma-exudate from L. longiflorum is carbohydrate, roughly $95 \%$ of which is polysaccharide (9), and that the growing pollen-tube specifically utilizes the polysaccharide in it for tube wall biosynthesis $(8,10)$. Additionally, Rosen et al. (5) suggested that there exists a similarity in high-molecular-weight constituents between stigma-exudate and stylar exudate. However, as seen in Fig. 2, the pollen-tube in the style grew much over that on stigmaexudate. In this connection, Ascher (2) has postulated that there is some special stylar substance as a possible factor which was required for compatible pollen-tube growth in the style. The present findings of poor pollen-tube growth on stigma-exudate seems to be a result of a lack of the special substance present in the style. In this sense, stigma-exudate might be different from stylar exudate in contents. The supposed factor seems to begin to be utilized by the pollentube between 5 and 12 hours after pollination (Fig. 3). Since the tube growth on stigma-exudate shows a nearly rectilinear increase during the first 12 hours, the pollentube seems to be maintaining a nearly uniform growth velocity by simply utilizing the nutrients contained in the exudate. On the other hand, tube growth in the style seems to be affected by a accelerative factor after a certain period, resulting in a parabolic growth curve. Although the nature or the reaction of the accelerative factor is not apparent, it might be possible, as Knox et al. showed in Poplar (7), that a reaction

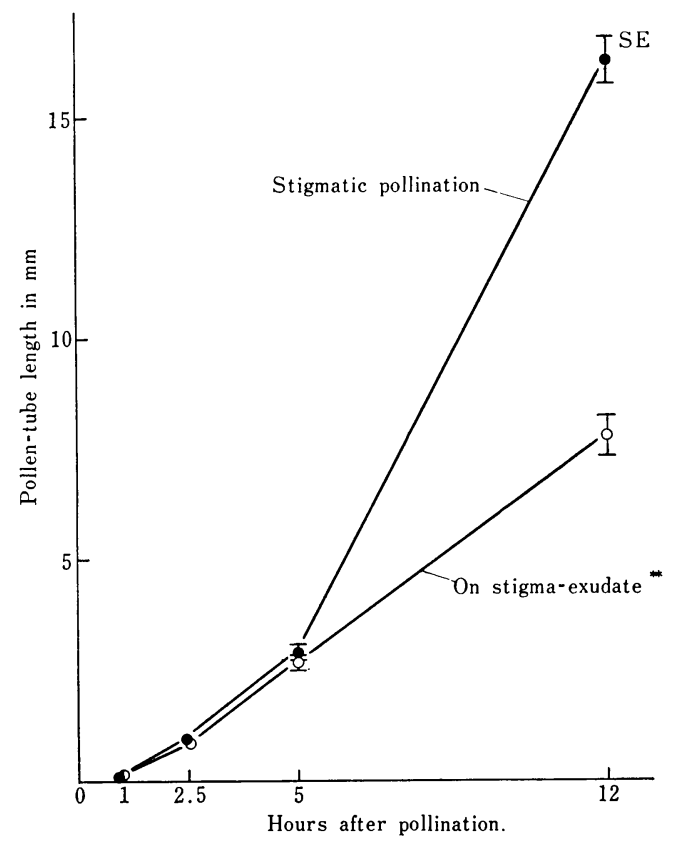

Fig. 3. Pollen-tube growths in interclonal stigmatic and 'stigma-exudate'- pollination of L. longiflorum.

* Mean of 8 replicates.

** Mean of 3 replicates.

$\mathrm{SE}:$ Standard error of the mean.

is triggered by the diffusion of a so-called recognition substance' which results in crosses between the same species being compatible. However, in Lilium, this interaction would take place between pollen-tube and style instead of between pollen and stigma, because there is no problem with pollen germination and pollen-tube penetration into the stigma even in the incompatible combinations, as mentioned above.

Statistically, there are significant differences among species in both the pollen-tube growth in interclonal stigmatic pollinations and in stigma-exudate pollination. The correlation coefficient between the length of the pollen-tube at 12 hours after stigmatic pollination and the length of the style is +0.826 , significant at the $\mathrm{P}=0.05$ level. The pollen-tube might grow faster in species with longer styles.

Interspecific crosses:

Interspecific crosses, it is necessary to compare the pollen-tube growth with its 'natural growth', that is, the growth in an inter- 
clonal (compatible) cross, to ascertain whether the pollen-tube growth in the style of another species is really 'bad' for the species itself or not. In Fig. 2, it is clear that the pollen-tube growths in interspecific crosses were actually worse than their 'natural growth'. But, the poor growth seems not to be a result of 'inhibition', but rather from impossibility of utilization of an accelerative factor, mentioned above, because the growth was not inferior to that in the case of 'interclonal stigma-exudate pollination' where the nutrients available for tube growth seemed to be sufficient; in fact the growth was even a little better than that with 'interclonal stigma-exudate pollination' in some cases.

As seen in Fig. 4, among the pollen-tubes of 5 interspecific crosses, those except $L$. regale maintained the same or a little better rate growth in the second 12 hours as compared with the first 12 hours after pollina-

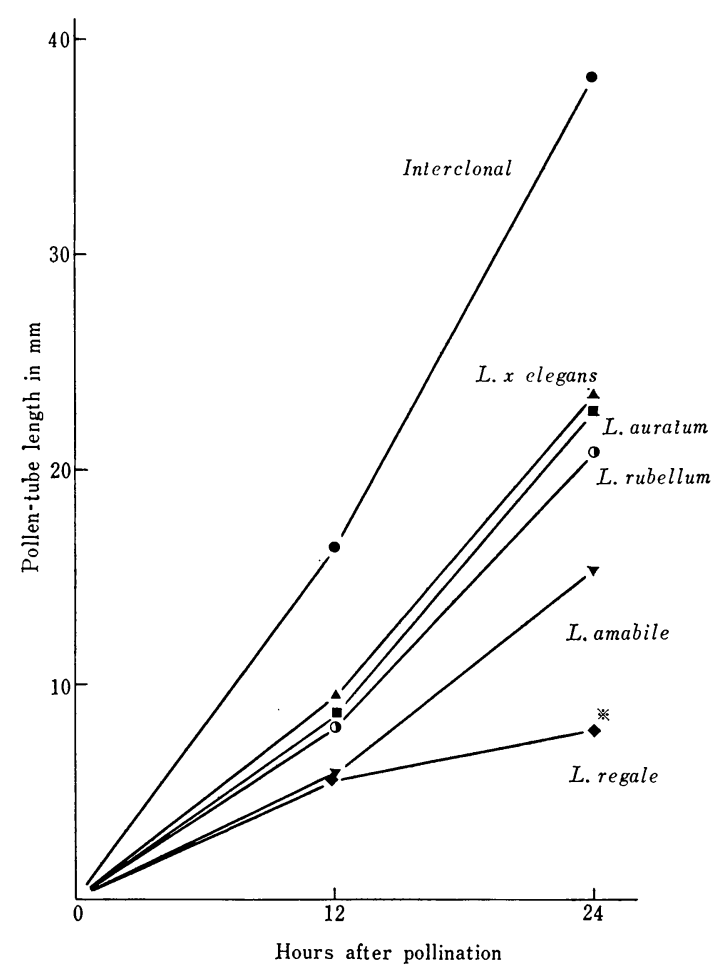

Fig.4. Pollen-tube growths in interclonal- and interspecific-stigmatic pollination on L.longiflorum.

* Abnormally swelled tip. tion; the pollen-tube growth of L.regale was inhibited. Such abnormal pollen-tube growth as noted with L. regale suggests an 'inhibiting' reaction which prevents the pollen-tube from taking up or metabolizing the substances contained in the stylar exudate. Ascher \& Drewlow (3) showed that this reaction could be partially countered by injection of stigma-exudate into the style.

The pollen-tube growths in interspecific crosses on L.longiflorum within 24 hours after pollination can be divided into 2 types as suggested by Ascher \& Drewlow: Those with 'half-growth interspecific incompatibility' and those with 'short-growth in terspecific incompatibility'. According to the results above, the former type would be mainly nutritive growth, not remarkably accelerated by some special factor; inhibiting reaction in the latter type would occur between 12 and 24 hours after pollination.

\section{Acknowledgement}

The author wishes to thank Professor Hiroshi Myodo of Hokkaido University for his valuable suggestions and for reading the manuscript.

\section{Literature Cited}

1. Asano, Y. and H. MYodo. 1977. Studies on crosses between distantly related species of Lilies. I. For the intrastylar pollination technique. J. Japan. Soc. Huit. Sci. 46(1): 59-65. (Japanese)

2. ASCHER, P.D. 1975. Special stylar property required for compatible pollen-tube growth in Lilium longiflorum Thunb. Bot. Gaz. 136 (3) : 317-321.

3. ASCHER, P.D. and L.W. DREWLOW. 1975. The effect of prepollination injection with stigmatic exudate on interspecific pollen tube growth in Lilium longiflorum Thunb. styles. Plant Science Letters 4:401-405.

4. ASCher, P. D. and S. J. Peloguin. 1968. Pollen tube growth and incompatibility following intra- and inter-specific pollinations in Lilium longiflorum. Amer. J. Bot. 55 (10) : 1230-1234.

5. DASHeK, W. V., H. R. THOMAS and W. G. ROSEN. 1971. Secretory cells of Lily pistil. II. Electron microscope cytochemistry of canal cells. Amer. J. Bot. 58(10) : 909-920. 
6. IWANAMI, Y. 1959. Physiological studies of pollen. J. Yokohama municipal Univ. Ser. C34 (Biol. 13) $116: 1-137$.

7. KNOX, R. B., R. R. WILLING and A. E. ASHFORD. 1972. Role of pollen-wall proteins as recognition substances in interspecific incompatibility in poplars. Nature $237: 381-383$.

8. KROH, M., C. LABARCA and F. LoEwUS. 1971. Use of pistil exudate for pollen tube wall biosynthesis in Lilium longiflorum. Pollen development and physiology (ed. J.H. Harrison) : 273-278. Butterworths, London.

9. LABARCA, C., M. KROH and F. LoEwUS. 1970.
The composition of stigmatic exudate from Lilium longiflorum. Labeling studies with Myo-Inositol, D-Glucose, and L-Proline. Plant Physiol. 46 : 150-156.

10. LABARCA, C. and F. LoEwUS. 1972. The nutritional role of pistil exudate in pollen tube wall formation in Lilium longiflorum. I. Utilization of injected stigmatic exudate. Plant Physiol. $50: 7-14$.

11. Myodo, H. 1962. Experimental studies on the sterility of some Lilium species. J. Fac. Agr. Hokkaido Univ. 51(2) : 70-122.

\title{
ユリの遠縁種間交雑に関する研究(第 6 報) \\ テッポウユリとの種間交配における花粉管伸長 (I)
}

\author{
浅野義 人 \\ (北海道大学農学部)
}

\begin{abstract}
摘要
種内（和合）交配：各々の種に拈いて，柱頭授粉で は, 柱頭粘液培地における花粉管伸長に比べ, その伸長 が著しく促進された.この花粉管伸長を促進する花柱内 要因は, 授粉後 $5 \sim 12$ 時間の間より作用するものと見ら れた。

種間（不和合）交配 : テッポウユリ花柱内の花粉管伸

るが，種内交配のような促進は起こらなかった．このこ とは，種間交配に打ける花粉管伸長遅緩が，積極的な “抑制”によるのではなく, 花柱内促進要因の利用不能 によるものであることを示唆するものと考光られた。し かし，ある種の交配では，授粉後 12〜24 時間の間に， 花粉管先端の異常を伴う伸長抑制が認められた.
\end{abstract} 長は，上記の柱頭粘液培地上のそれと同じか，やや上回 